Volume 1 Issue 1, March 2017: pp. 86-104. Copyright (c) 2017 HOLREV. Faculty of Law, Halu Oleo University, Kendari, Southeast Sulawesi, Indonesia. ISSN: 2548-1762 | e-ISSN: 2548-1754. Open Access at: http://ojs.uho.ac.id/index.php/holrev/

\title{
Perlindungan Terhadap Korban Kekerasan dalam Rumah Tangga di Kabupaten Sidoarjo Pasca Berlakunya Undang- Undang Nomor 23 Tahun 2004
}

\author{
Legal Protection towards Victim of Domestic Violence in Sidoarjo Regency \\ upon Post of Law 23 of 2004, Domestic Violence
}

\author{
Emy Rosna Wati \\ Fakultas Hukum Universitas Muhammadiyah Sidoarjo \\ E-mail: emy_lawyer@rocketmail.com
}

\begin{abstract}
Domestic violence has obviously become "an ice mountain". In fact, the victim usually becomes victim due to domestic violence. However, non-of-them ready to report his or her cases to law enforcer hence they considered to open their familydisgrace and tend to afraid to report because it is obstructed and even intimidated by a criminal. Therefore Government has promulgated the Law 23 of 2004, Elimination of Domestic Violence. This study aimed to analyze in Sidoarjo Regency, East Java, Indonesia. The used method is social legal research as well as supported by primer data such as several documents and interviews with the victim of domestic violence that located in Sidoarjo Regency and Integrated Service Center for Women and Children Empowerment \{Pusat Pelayanan Terpadu Pemberdayaan Perempuan dan Anak (P2TP2A)\}. Furthermore, this research would be analyzed descriptivequalitative. Accomplished result was to find out the facts and to what extend victim of domestic violence should be given their rights as mentioned in the law of Elimination of Domestic Violence particularly in Sidoarjo Regency.
\end{abstract}

Kata kunci: Protection; Domestic Violence.

Abstrak: Kekerasan dalam rumah tangga merupakan fenomena "gunung es". Dalam kenyataannya korban yang selalu mengalami kekerasan dalam rumah tangga. Tidak semuanya bersedia melaporkan kasusnya kepada pihak yang berwajib. Dengan alasan bahwa mereka beranggapan membuka aib keluarga dan cenderung takut untuk melaporkan karena dihalang-halangi bahkan diintimidasi oleh pelaku. Oleh karena itu pemerintah mengeluarkan Undang-undang Nomor 23 tahun 2004 tentang Penghapusan Kekerasan Dalam Rumah Tangga. Penelitian ini dilakukan untuk menganalisa pelaksanaan undang - undang tersebut di Kabupaten Sidoarjo dengan menggunakan metode yuridis sosiologis (socio legal research) ditunjang dengan data primer berupa dokumen dan wawancara dengan korban kekerasan dalam rumah tangga dilingkungan Kabupaten Sidoarjo yang ditangani oleh Pusat 
Pelayanan Terpadu Pemberdayaan Perempuan dan Anak (P2TP2A) untuk kemudian dianalisis secara deskriptif kualitatif. Hasil penelitian yang hendak dicapai adalah menemukan fakta sejauh mana korban kekerasan dalam rumah tangga dapat terlindungi hak-haknya sebagaimana tercantum dalam undang-undang penghapusan kekerasan dalam rumah tangga khususnya di Kabupaten Sidoarjo.

Kata kunci: Perlindungan; Kekerasan; Dalam Rumah Tangga.

\section{PENDAHULUAN}

Hukum pidana secara tradisional diartikan sebagai "bentuk peraturan-peraturan tentang hukuman atau pidana, akan tetapi, praktiknya hingga sekarang belum ada kesatuan pendapat untuk memberlakukan salah satu definisi hukum pidana secara umum". ${ }^{1} \mathrm{Hal}$ tidak adanya suatu pemberlakuan definisi hukum pidana secara umum disebabkan karena "cakupan hukum pidana sangat luas dan para ahli di dalam memberikan definisi hukum pidana dari sudut pandang yang berbeda-beda, sehingga perbedaan sudut pandang tersebut menyebabkan istilah hukum pidana mempunyai lebih dari definisi". ${ }^{2}$ Menurut Wirjono Prodjodikoro, istilah Belanda "strafbaarfeit" yang sebenarnya merupakan istilah resmi dalam Kitab Undang-Undang Hukum Pidana (KUHP) yang sekarang berlaku di Indonesia. ${ }^{3}$ Kemudian menurut Roni Wiyanto hukum pidana, banyak sarjana yang menyebutnya dengan perbuatan pidana, tindak pidana, peristiwa pidana dan lainnya, itu semua merupakan terjemahan dari bahasa Belanda strafbaar feit. ${ }^{4}$

Tindak pidana atau perbuatan pidana secara umum telah diatur dalam KUHP, namun dengan pertimbangan bahwa setiap warga negara berhak mendapatkan rasa aman dan bebas dari segala bentuk kekerasan sesuai dengan falsafah Pancasila dan UndangUndang Dasar Negara Republik Indonesia Tahun 1945. Segala bentuk kekerasan, terutama kekerasan dalam rumah tangga, merupakan pelanggaran hak asasi manusia dan kejahatan terhadap martabat kemanusiaan serta bentuk diskriminasi yang harus dihapus. Korban dari kekerasan dalam rumah tangga, yang kebanyakan adalah perempuan, harus mendapat perlindungan dari negara dan/atau masyarakat agar terhindar dan terbebas dari kekerasan atau ancaman kekerasan, penyiksaan, atau perlakuan yang merendahkan derajat dan martabat kemanusiaan.

\footnotetext{
Roni Wiyanto, Asas-Asas Hukum Pidana Indonesia, Mandar Maju, Bandung 2012, h. 3.

Ibid.

Wirjono Prodjodikoro, Asas-Asas Hukum Pidana di Indonesia, Refika Aditama, Jakarta, 2008, h. 59

Ibid., h. 160.
} 
Dalam kenyataannya kasus kekerasan dalam rumah tangga banyak terjadi, sedangkan sistem hukum di Indonesia belum menjamin perlindungan terhadap korban kekerasan dalam rumah tangga. ${ }^{5}$

Untuk itu diadakan pembaruan hukum yang berpihak pada kelompok rentan atau tersubordinasi, khususnya perempuan, menjadi sangat diperlukan sehubungan dengan banyaknya kasus kekerasan, terutama kekerasan dalam rumah tangga. Pembaruan hukum tersebut diperlukan karena undang-undang yang ada belum memadai dan tidak sesuai lagi dengan perkembangan hukum masyarakat. Oleh karena itu, diperlukan pengaturan tentang tindak pidana kekerasan dalam rumah tangga secara tersendiri karena mempunyai kekhasan, walaupun secara umum di dalam Kitab Undang-Undang Hukum Pidana telah diatur mengenai penganiayaan dan kesusilaan serta penelantaran orang yang perlu diberikan nafkah dan kehidupan. Undang-Undang tentang Kekerasan dalam Rumah tangga ini terkait erat dengan beberapa peraturan perundang-undangan lain yang sudah berlaku sebelumnya, antara lain, Undang-Undang Nomor 1 Tahun 1946 tentang Kitab Undang-Undang Hukum Pidana serta Perubahannya.

Berdasarkan uraian tersebut di atas, ada suatu pembaharuan hukum pidana khususnya mengenai penganiayaan pada umumnya dan penganiayaan dalam lingkup rumah tangga atau yang dikenal dengan penghapusan kekerasan dalam rumah tangga, dengan permasalahan, yakni "Bagaimanakah perlindungan korban kekerasan dalam rumah tangga setelah berlakunya Undang-Undang nomor 23 tahun 2004 di Kabupaten Sidoarjo?"

\section{METODE PENELITIAN}

Penelitian lapangan (field research) dikenal dengan penelitian Hukum Empiris adalah pengumpulan materi atau bahan penelitian yang harus diupayakan atau dicari sendiri oleh karena belum tersedia. Kegiatan yang dilakukan dapat berbentuk membuat pedoman wawancara dan diikuti dengan mencari serta mewawancarai para informan, menyusun kuesioner dan kemudian mengedarkan kuesioner itu pada responden, melakukan pengamatan (observasi).

5 Konsideran Bagian Menimbang Undang-Undang Republik Indonesia Nomor 23 Tahun 2004 Tentang Penghapusan Kekerasan Dalam Rumah Tangga. 


\section{ANALISIS DAN PEMBAHASAN}

\section{Perlindungan Hukum}

Perlindungan hukum menurut Satijipto Raharjo, Perlindungan hukum adalah "memberikan pengayoman terhadap hak asasi manusia yang dirugikan orang lain dan perlindungan itu diberikan kepada masyarakat agar dapat menikmati semua hak-hak yang diberikan oleh hukum". 6 Menurut Maria Theresia Geme "Perlindungan hukum berkaitan dengan tindakan negara untuk melakukan sesuatu dengan (memberlakukan hukum negara secara eksklusif) dengan tujuan untuk memberikan jaminan kepastian hak-hak seseorang atau kelompok orang".7 Philipus M. Hadjon menyatakan "sarana perlindungan hukum ada dua yaitu sarana perlindungan hukum preventif dan sarana perlindungan hukum represif. Sarana perlindungan hukum preventif terutama erat kaitannya dengan asas freisermessen sebagai bentuk perlindungan hukum secara umum sedangkan sarana perlindungan hukum represif di Indonesia ditangani oleh badan-badan pengadilan dalam lingkungan peradilan umum, instansi pemerintah yang merupakan lembaga banding administrasi dan badan-badan khusus". ${ }^{8}$ sarana perlindungan hukum represif yang dilakukan oleh pengadilan dalam bentuk penjatuhan pidana kepada pelaku.

Korban kekerasan dalam rumah tangga mendapat perlindungan hukum dari segi preventif sebagaimana dalam pasal 351 Kitab Undang-Undang Hukum Pidana (KUHP) dan UU PKDRT. Secara preventif, korban perlindungan hukum dapat menempuh jalur hukum dengan melaporkan pelaku tindak pidana dalam lingku rumah tangga untuk ditindaklanjuti sebagai pelaku tindak pidana kekerasan dalam rumah tangga.

Perlindungan hukum menurut Satijipto Raharjo, Perlindungan hukum adalah "memberikan pengayoman terhadap hak asasi manusia yang dirugikan orang lain dan perlindungan itu diberikan kepada masyarakat agar dapat menikmati semua hak-hak yang diberikan oleh hukum". ${ }^{9}$ Menurut Maria Theresia Geme "Perlindungan hukum berkaitan dengan tindakan negara untuk melakukan sesuatu dengan (memberlakukan hukum negara secara eksklusif) dengan tujuan untuk memberikan jaminan kepastian hak-hak

Satjipto Raharjo, Ilmu Hukum, CitraAditya Bakti, Bandung, 2000, hlm. 54.

Maria Theresia Geme, Perlindungan Hukum terhadap Mayarakat Hukum Adat dalam Pengelolaan Cagar Alam Watu Ata Kabupaten Ngada, Provinsi Nusa Tenggara TImur, disertasi Program Doktor Ilmu Hukum Fakultas Hukum Universitas Brawijaya Malang, 2012, hlm. 99.

8 Philipus Hadjon M dan Tatiek Sri Djatmiati 2005 Argumentasi Hukum, Yogyakarta :Gajahmada Press

9 Satjipto Raharjo, Ilmu Hukum, CitraAditya Bakti, Bandung, 2000, hlm. 54. 
seseorang atau kelompok orang". ${ }^{10}$ Philipus M. Hadjon menyatakan "sarana perlindungan hukum ada dua yaitu sarana perlindungan hukum preventif dan sarana perlindungan hukum represif. Sarana perlindungan hukum preventif terutama erat kaitannya dengan asas freisermessen sebagai bentuk perlindungan hukum secara umum sedangkan sarana perlindungan hukum represif di Indonesia ditangani oleh badan-badan pengadilan dalam lingkungan peradilan umum, instansi pemerintah yang merupakan lembaga banding administrasi dan badan-badan khusus". ${ }^{11}$ sarana perlindungan hukum represif yang dilakukan oleh pengadilan dalam bentuk penjatuhan pidana kepada pelaku.

Korban kekerasan dalam rumah tangga mendapat perlindungan hukum dari segi preventif sebagaimana dalam pasal 351 KUHP dan UU PKDRT. Secara preventif, korban perlindungan hukum dapat menempuh jalur hukum dengan melaporkan pelaku tindak pidana dalam lingku rumah tangga untuk ditindaklanjuti sebagai pelaku tindak pidana kekerasan dalam rumah tangga.

\section{Perlindungan Hukum Tindak Pidana Penganiayaan Sebelum Diundangkan Undang- Undang Penghapusan kekerasan dalam Rumah Tangga}

Uraian sebelumnya telah disinggung bahwa diundangkannya UU PKDRT sebagai suatu bentuk pembaharuan dari penganiayaan sebagaimana diatur dalam KUHP sebagai aturan yang bersifat umum, sehingga UU PKDRT merupakan bentuk lex spesialis derogat lex generalis dari KUHP. Suatu dikatakan sebagai perbuatan atau tindakan, jika tindakan tersebut telah dirumuskan terlebih dahulu sebagai perbuatan pidana. Hal tersebut diatur dalam Pasal 1 ayat (1) KUHP yang menentukan "tiada suatu perbuatan boleh dihukum, melainkan atas kekuatan ketentuan pidana dalam undang-undang, yang ada terdahulu dari perbuatan itu", yang dikenal dengan asas legalitas. Ketentuan Pasal 1 ayat (1) KUHP tersebut di dalamnya terkandung hal:

1) Suatu perbuatan dapat dipidana kalau termasuk ketentuan pidana menurut undang-undang. Oleh karena itu, pemidanaan berdasarkan hukum tidak tertulis tidak dimungkinkan;

2) Ketentuan pidana itu harus lebih dahulu ada dari perbuatan itu. dengan kata lain, ketentuan pidana itu harus sudah berlaku ketika perbuatan itu dilakukan.

\footnotetext{
10 Maria Theresia Geme, Perlindungan Hukum terhadap Masyarakat Hukum Adat dalam Pengelolaan Cagar Alam Watu Ata Kabupaten Ngada, Provinsi Nusa Tenggara Timur, disertasi Program Doktor Ilmu Hukum Fakultas Hukum Universitas Brawijaya Malang, 2012, hlm. 99.

11 Philipus Hadjon M dan Tatiek Sri Djatmiati 2005 Argumentasi Hukum, Yogyakarta :Gajahmada Press
} 
Oleh karena itu, ketentuan tersebut tidak berlaku surut, baik mengenai ketetapan dapat dipidana maupun sanksi. ${ }^{12}$

Penganiayaan sebagai tindak pidana secara umum didasarkan atas ketentuan pasal 351 KUHP, dan penganiayaan (kekerasan) dalam rumah tangga diatur dalam UU PKDRT, yang berarti sesuai dengan asas legalitas telah ada peraturan perundang-undangan yang mengaturnya.

Hukum pidana tidak hanya memberikan pengertian tentang perbuatan yang dilarang oleh suatu aturan hukum, larangan mana disertai ancaman (sanksi) yang berupa pidana tertentu bagi barangsiapa melanggar larangan tersebut, melainkan juga mencakup hal berkaitan dengan pengenaan pidana dan cara bagaimana pidana tersebut dapat dilaksanakan. Larangan tersebut ditujukan kepada perbuatannya, yaitu suatu keadaan atau kejadian yang ditimbulkan oleh kelakuan atau perbuatan seseorang, sedangkan ancaman pidananya atau sanksinya ditujukan kepada pelaku yang melakukan perbuatan pidana yang biasanya disebut dengan perkataan "barangsiapa" yaitu pelaku perbuatan pidana sebagai subyek hukum, yaitu pendukung hak dan kewajiban dalam bidang hukum.

Di dalam ilmu pengetahuan hukum pidana mengenal beberapa jenis delik yang penting dalam ajaran causalitas adalah perbedaan antara delik formal dan delik materiil. Delik formal yang dimaksud adalah delik yang telah dianggap penuh dengan dilakukannya suatu perbuatan yang dilarang dan diancam dengan suatu hukuman. ${ }^{13}$

Tindak pidana penganiayaan dalam KUHP diatur pada Bab XX tentang Penganiayaan mulai dari Pasal 351 sampai dengan Pasal 358 KUHP. Pada pembahasan berikutnya materinya dibatasi mengenai tindak pidana penganiayaan dalam Pasal 351 KUHP.

Pasal 351 KUHP menentukan:

(1) Penganiayaan diancam dengan pidana penjara paling lama dua tahun delapan bulan atau pidana denda paling banyak empat ribu lima ratus rupiah.

(2) Jika perbuatan mengakibatkan luka-luka berat yang bersalah diancam dengan pidana penjara paling lama lima tahun.

(3) Jika mengakibatkan mati diancam dengan pidana penjara paling lama tujuh tahun.

(4) Dengan penganiayaan disamakan sengaja merusak kesehatan.

12 D. Schaffmeister, N. Keijzer \& Sutorius, Hukum Pidana, Citra Aditya Bakti, Bandung, 2011, h. 3

13 Teguh Prasetyo, Hukum Pidana, Cet. III, Rajawali Press, Jakarta, 2012, h. 167. 
Di dalam rumusan Pasal 351 (1) KUHP, tidak terdapat unsur-unsur dari pada kejahatan ini, hanya saja disebutan kualifikasi atau sebutan penganiayaan sebagai kejahatan saja.

Penganiayaan menurut Kamus Bahasa Indonesia diartikan sebagai perbuatan atau perlakuan yang sewenang-wenang, penyiksaan, penindasan dan lain sebagainya. Perihal penganiayaan, Soesilo mengemukakan bahwa perbuatan itu misalnya menempeleng kepala. Walaupun perbuatan itu menimbulkan rasa sakit pada si penderita, namun tidak menyebabkan menjadi sakit dan dapat menjalankan jabatan serta dapat melakukan pekerjaannya sehari-hari. Sebaliknya melukai jari kelingkung seorang pemain biola, walau-pun kecil sekali, namun apabila perbuatan itu menyebabkan si pemain biola tidak dapat bermain orkes, satu-satunya profesi yang dapat jalankan, tidak dapat digolongkan sebagai penganiayaan ringan. ${ }^{14}$

Penganiayaan sebagaimana Pasal 351 KUHP, tidak terdapat penjelasan lebih lanjut. Menurut Sugandhi, bahwa "undang-undang tidak menegaskan apa arti sesungguhnya dari penganiayaan. Menurut yurisprudensi, arti penganiayaan adalah perbuatan dengan sengaja yang menimbulkan rasa tidak enak, rasa sakit atau luka".15 Dikatakan telah melakukan penganiayaan tidak perbuatan yang menimbulkan rasa tidak enak, rasa sakit atau luka, yang berarti jika perbuatan tersebut dilakukan tidak sengaja, maka tidak dapat dikatakan telah melakukan penganiayaan. Hal ini berarti bahwa penganiayaan tersebut merupakan suatu bentuk kejahatan. Dikualifikasikan sebagai kejahatan, yang berarti bahwa rasa sakit yang diderita oleh seseorang disebabkan karena tindakan orang lain dilakukan dengan sengaja, sesuai dengan yang dikemukakan oleh Sianturi sebagai berikut: "Unsur kesalahan disini harus dengan sengaja”.16

Unsur kesengajaan merupakan suatu hal pokok dalam hukum pidana yang merupakan suatu perbuatan melawan hukum. Perihal perbuatan melawan hukum, Moeljatno membedakannya antara sifat melawan hukum formal dan sifat melawan hukum yang materiil. Sifat melawan hukum formal, apabila perbuatan telah mencocoki larangan undang-undang, maka terjadi kekeliruan. Letak melawan hukum perbuatan sudah ternyata, dari sifat melanggarnya ketentuan undang-undang, kecuali jika termasuk pengecualian yang telah ditentukan oleh undang-undang pula. Baginya melawan hukum

14 Soesilo, KUHP Beserta Penjelasannya Pasal Demi Pasal , Poeliteia, Bogor, 1998, h.

15 Sugandhi, KUHP dan Penjelasannya, Usaha Nasional, Surabaya, 2001, h. 366.

16 Sianturi, Tindak Pidana di KUHP Berikut Uraiannya, Alumni KHM. PTHM, Jakarta,1989, h. 503. 
berarti melawan undang-undang, sebab hukum adalah undang-undang, sedangkan sifat melawan hukum yang materiil berpendapat bahwa belum tentu kalau semua perbuatan yang mencocoki larangan undang-undang bersifat melawan hukum. Baginya ini yang dinamakan hukum bukanlah undang-undang saja, di samping undang-undang (hukum yang tertulis) ada pula hukum yang tidak tertulis yaitu norma-norma atau kenyataankenyataan yang berlaku dalam masyarakat. ${ }^{17}$

Selanjutnya Sianturi mengemukakan bahwa dengan demikian petindak menghendaki dan mengetahui tindakan yang dilakukannya dan menghendaki sakit atau lukanya objek dan sebagainya. Bahkan dapat juga dikatakan bahwa tujuan dari si petindak atau subjek melakukan suatu tindakan (misalnya memukul, memotong, membedah) adalah untuk membuat sakit atau luka seseorang. ${ }^{18}$ Meskipun penganiayaan pada Pasal 351 KUHP termasuk kejahatan yang dilakukan dengan sengaja, tidak berarti terhadap pelakunya akan dijatuhi pidana, karena sebagaimana dikemukakan oleh Sianturi bahwa unsur bersifat melawan hukum yang kita anut dalam rangka penerapan hukum pidana memaksa kita harus selalu mengadakan penilaian apakah tindakan subjek bersifat melawan hukum atau tidak. Seorang ayah pada dasarnya sampai suatu tingkat tertentu dipandang berwenang "menghajar" anaknya yang nakal. Karenanya dipandang bahwa tindakannya itu tidak bersifat melawan hukum. Sudah barang tentu, apabila melampaui kewajaran maka kepadanya diterapkan Pasal 356. Sampai sejauhmana batas-batas dari kewajaran itu haruslah diselesaikan secara kasuistis. ${ }^{19}$

Penganiayaan tersebut apabila berakibat luka berat, yang bersalah dipidana dengan pidana penjara selama-lamanya lima tahun. Pasal 351 KUHP tidak memberikan definisi mengenai luka berat. Luka berat yang dimaksud adalah sebagaimana Pasal 90 KUHP, yang menentukan bahwa:

Luka berat berarti:

1. jatuh sakit atau mendapat luka yang tidak memberi harapan akan sembuh sama sekali, atau yang menimbulkan bahaya maut;

2. tidak mampu terus-menerus untuk menjalankan tugas jabatan atau pekerjaan pencarian;

3. kehilangan salah satu pancaindra;

17 PAF. Lamintang, Op. cit, h. 130.

18 Sianturi, Loc. Cit.

19 Ibid., h. 503-504. 
4. mendapat cacat berat;

5. menderita sakit lumpuh;

6. terganggunya daya pikir selama empat minggu lebih;

7. gugur atau matinya kandungan seorang perempuan.

Dengan penganiayaan sebagaimana tersebut dalam Pasal 351 KUHP, dijelaskan sebagai berikut:

1) Perbuatan yang menimbulkan perasaan tidak enak misalnya mendorong orang terjun ke dalam kubangan air sehingga basah, menyuruh orang berdiri di terik matahari dan sebagainya;

2) Perbuatan yang menimbulkan rasa sakit misalnya mencubit, mendepak, memukul, menempeleng dan sebagainya;

3) Perbuatan yang mengakibatkan luka misalnya mengiris, memotong, menusuk dengan benda tajam dan sebagainya;

4) Perbuatan yang dapat merusak kesehatan misalnya menyiram dengan air aki. ${ }^{20}$

Penganiayaan (kekerasan) baik fisik maupun psikis sebelum diundangkannya UU PKDRT didasarkan atas penganiayaan sebagaimana diatur dalam KUHP, yang membedakan antara penganiayaan ringan dengan penganiayaan berat. Penganiayaan dalam KUHP didasarkan atas laporan adanya penganiayaan, penanganannya tidak diadakan secara khusus, melainkan sebagaimana pelaku tindak pidana umumnya.

\section{Perlindungan hukum dalam Undang-Undang Penghapusan kekerasan dalam Rumah Tangga}

Perlindungan menurut Undang-Undang penghapusan kekerasan dalam rumah tangga adalah segala upaya yang ditujukan untuk memberikan rasa aman kepada korban yang dilakukan oleh pihak keluarga, advokat, lembaga sosial, kepolisian, kejaksaan, pengadilan atau pihak lainnya baik sementara maupun berdasarkan penetapan pengadilan. ${ }^{21}$

Kekerasan dalam Rumah tangga diatur dalam UU PKDRT. Diundangkannya UUPKDRT dengan maksud untuk menjamin keutuhan dalam rumah tangga. Sebagaimana dalam Penjelasan Umum bahwa keutuhan dan kerukunan rumah tangga yang bahagia, aman, tenteram, dan damai merupakan dambaan setiap orang dalam rumah tangga.

\footnotetext{
20 Salim HS dan Erlies Septiana Nurbani, Penerapan Teori Hukum pada Penelitian Tesis dan Disertasi, RajaGrafindo Persada, Jakarta, 2013, h. 38

21 Undang - Undang nomor 23 tahun 2004 tentang Penghapuan kekerasan dalam rumah tangga pasal 1
} 
Negara Republik Indonesia adalah negara yang berdasarkan Ketuhanan Yang Maha Esa dijamin oleh Pasal 29 Undang-Undang Dasar Negara Republik Indonesia Tahun 1945. Dengan demikian, setiap orang dalam lingkup rumah tangga dalam melaksanakan hak dan kewajibannya harus didasari oleh agama. Hal ini perlu terus ditumbuh-kembangkan dalam rangka membangun keutuhan rumah tangga. Untuk mewujudkan keutuhan dan kerukunan tersebut, sangat tergantung pada setiap orang dalam lingkup rumah tangga, terutama kadar kualitas perilaku dan pengendalian diri setiap orang dalam lingkup rumah tangga tersebut, sebagaimana Penjelasan Umum UU PKDRT. Hal tersebut sebagaimana dijelaskan dalam Penjelasan Umum UU PKDRT.

Keutuhan dan kerukunan rumah tangga dapat terganggu jika kualitas dan pengendalian diri tidak dapat dikontrol, yang pada akhirnya dapat terjadi kekerasan dalam rumah tangga sehingga timbul ketidakamanan atau ketidakadilan terhadap orang yang berada dalam lingkup rumah tangga tersebut. ${ }^{22}$

Ketentuan dalam UUPKDRT terdiri atas kekerasan dan rumah tangga. Pengertian kekerasan menurut Pasal 16 Rekomendasi Umum No. 19 Perserikatan Bangsa-Bangsa (yang selanjutnya disebut PBB) menyatakan, bahwa kekerasan dalam rumah tangga adalah salah satu bentuk kekerasan terhadap perempuan yang paling berbahaya. Hal ini lazim pada semua masyarakat. Dalam hubungan kekeluargaan di segala umur, perempuan menderita segala macam penderitaan, termasuk pemukulan, perkosaan, bentuk-bentuk lain dari penyerangan seksual, mental yang dilakukan oleh sikap-sikap tradisional. Ketergantungan otonomi, memaksa perempuan untuk bertahan pada hubungan yang didasarkan atas kekerasan-kekerasan. Pencabutan/ pengambil-alihan tanggung jawab keluarga oleh laki-laki dapat juga disebut sebagai bentuk kekerasan dan paksaan. Bentukbentuk dari kekerasan ini menempatkan perempuan pada resiko kekerasan dan paksaan. Juga menempatkan perempuan pada resiko kesehatan dan menghalangi kesempatan untuk berpartisipasi dalam kehidupan keluarga dan kehidupan umum atas dasar suatu kesamaan. $^{23}$

Menurut Umu Hilmy mengenai pengertian kekerasan dijelaskan bahwa terminologi kesehatan, kekerasan dalam rumah tangga sesungguhnya berhubungan dengan ibu rumah tangga atau istri sebagai korban. Istilah kekerasan dalam rumah tangga dalam literatur

22 Ibid.

23 http://LBH APIK.Perserikatan Bangsa Bangsa.com/Rekomendasi Umum No. 19 tentang Kekerasan Terhadap Perempuan 
barat umumnya dipergunakan secara bervariasi, misalnya domestic violence, family violence, wife abuse. Gelles mendefinisikan kekerasan dalam keluarga (Gamily Violence) sebagai: "Seorang yang melakukan tindakan pemukulan menampar menyiksa, menganiaya ataupun pelemparan benda-benda kepada orang lain yang menjadi pokok persoalan yang menyangkut kekerasan dalam keluarga." 24

Hal ini berarti bahwa kekerasan dalam rumah tangga yang dimaksud adalah seorang diartikan sebagai suatu selaku pemegang kendali dalam rumah tangga, melakukan tindakan pemukulan menampar menyiksa, menganiaya ataupun pelemparan benda-benda kepada orang lain yang menjadi pokok persoalan yang menyangkut kekerasan dalam keluarga.

Rumah tangga "merupakan organisasi terkecil dalam masyarakat yang terbentuk karena adanya ikatan perkawinan. Biasanya rumah tangga terdiri atas ayah, ibu dan anakanak". ${ }^{25}$ Pada perkembangan berikutnya pengertian rumah tangga diperluas dengan pertimbangan "seringkali dalam rumah tangga juga ada sanak saudara yang ikut bertempat tinggal, misalnya orang tua, baik dari suami atau istri, saudara kandung/tiri dari kedua belah pihak, kemenakan dan keluarga yang lain, yang mempunyai hubungan darah". ${ }^{26}$

Kekerasan dalam rumah tangga menurut Pasal 1 angka 1 UUPKDRT adalah setiap perbuatan terhadap seseorang terutama perempuan, yang berakibat timbulnya kesengsaraan atau penderitaan secara fisik, seksual, psikologis, dan/atau penelantaran rumah tangga termasuk ancaman untuk melakukan perbuatan, pemaksaan, atau perampasan kemerdekaan secara melawan hukum dalam lingkup rumah tangga. Kekerasan sebagaimana telah diuraikan di atas dilakukan terhadap perempuan yang berakibat timbulnya kesengsaraan atau penderitaan secara fisik, seksual, psikologis, dan/atau penelantaran rumah tangga.

Menurut Pasal 2 UUPKDRT, Lingkup rumah tangga dalam Undang-Undang ini meliputi:

(1) Lingkup rumah tangga dalam Undang-Undang ini meliputi :

a. suami, istri, dan anak;

\footnotetext{
24 Penanganan Kasus-kasus Trafiking Berperspektif Gender Oleh Jaksa dan Hakim, Universitas Negeri Malang, 2006, h. 76.

25 Moerti Hadiati Soeroso, Kekerasan Dalam Rumah Tangga, Dalam Perspektif Yuridis-Viktimologi, Sinar Grafika, Jakarta, 2010, h. 61.

26 Ibid.
} 
b. orang-orang yang mempunyai hubungan keluarga dengan orang sebagaimana dimaksud pada huruf a karena hubungan darah, perkawinan, persusuan, pengasuhan, dan perwalian, yang menetap dalam rumah tangga; dan/atau

c. orang yang bekerja membantu rumah tangga dan menetap dalam rumah tangga tersebut.

(2) Orang yang bekerja sebagaimana dimaksud pada huruf c dipandang sebagai anggota keluarga dalam jangka waktu selama berada dalam rumah tangga yang bersangkutan.

Menurut penjelasan Pasal 2 ayat (1) UUPKDRT, bahwa: Yang dimaksud dengan anak dalam ketentuan ini adalah termasuk anak angkat dan anak tiri. Yang dimaksud dengan "hubungan perkawinan" dalam ketentuan ini, misalnya mertua, menantu, ipar, dan besan.

Perihal jenis kekerasan sebagaimana Pasal 5 UUPKDRT, yang menentukan, setiap orang dilarang melakukan kekerasan dalam rumah tangga terhadap orang dalam lingkup rumah tangganya, dengan cara:
a. kekerasan fisik;
b. kekerasan psikis;
c. kekerasan seksual; atau
d. penelantaran rumah tangga.

Satu di antara kekerasan dalam rumah tangga yaitu kekerasan fisik menurut Pasal 6 UUPKDRT bahwa Kekerasan fisik adalah perbuatan yang mengakibatkan rasa sakit, jatuh sakit, atau luka berat.

Terhadap pelaku tindak pidana kekerasan fisik dalam Pasal 44 UUPKDRT, yang menentukan: "Setiap orang yang melakukan perbuatan kekerasan fisik dalam lingkup rumah tangga sebagaimana dimaksud dalam Pasal 5 huruf a dipidana dengan pidana penjara paling lama 5 (lima) tahun atau denda paling banyak Rp 15.000.000,00 (lima belas juta rupiah)".

Ketentuan Pasal 44 UUPKDRT sebagaimana tersebut di atas, di dalamnya terkandung unsur subyeknya yaitu setiap orang, yang berarti orang perorangan dalam lingkup rumah tangga, sehingga pelakunya bisa suami, istri, dan anak; orang-orang yang mempunyai hubungan keluarga dengan orang karena hubungan darah, perkawinan, 
persusuan, pengasuhan, dan perwalian, yang menetap dalam rumah tangga; dan/atau orang yang bekerja membantu rumah tangga dan menetap dalam rumah tangga tersebut.

Unsur Pasal 44 ayat (1) UUPKDRT adalah: 1) Melakukan perbuatan kekerasan fisik, 2) dalam lingkup rumah tangga.

Kekerasan menurut Pasal 1 angka 1 UUPKDRT, adalah setiap perbuatan terhadap seseorang terutama perempuan, yang berakibat timbulnya kesengsaraan atau penderitaan secara fisik, seksual, psikologis, dan/atau penelantaran rumah tangga termasuk ancaman untuk melakukan perbuatan, pemaksaan, atau perampasan kemerdekaan secara melawan hukum.

Memperhatikan uraian sebagaimana tersebut di atas dapat dijelaskan bahwa kekerasan dalam lingkup rumah tangga dalam lingkup kekerasan fisik dapat dijelaskan bahwa suatu perbuatan yang dilakukan secara sengaja dengan kekuatan fisik, mengakibatkan rasa sakit, jatuh sakit, atau luka berat berkaitan dengan badan ini termasuk juga perbuatan-perbuatan lainnya di mana hanya sepihak yang menggunakan/digunakan alat.

\section{Perlindungan korban kekerasan dalam rumah tangga setelah berlakunya UUPKDRT}

Undang-undang Nomor 23 Tahun 2004 digunakan sebagai payung hukum penyelesaian kasus-kasus kekerasan dalam rumah tangga. Undang-undang ini dianggap sebagai salah satu peraturan yang melakukan terobosan hukum karena terdapat beberapa pembaharuan hukum pidana yang belum pernah diatur oleh undang-undang sebelumnya.

Terobosan hukum yang terdapat dalam undang-undang tersebut tidak hanya dalam bentuk-bentuk tindak pidananya, tetapi juga dalam proses beracaranya. Antara lain dengan adanya terobosan hukum untuk pembuktian bahwa korban menjadi saksi utama dengan didukung satu alat bukti petunjuk. sehingga diharapkan dengan adanya terobosan hukum ini kendala-kendala dalam pembuktian karena tempat terjadinya KDRT umumnya di ranah domestik.

Terobosan hukum yang pertama diakomodir dalam undang-undang ini adalah bentuk-bentuk kekerasan yang mencakup kekerasan fisik, kekerasan psikis, kekerasan seksual dan kekerasan ekonomi atau penelantaran keluarga. Seperti sudah diketahui sebelum ada undang-undang kekerasan dalam rumah tangga kekerasan yang dikenal dalam hukum Indonesia hanya kekerasan fisik dengan istilah penganiayaan. Dengan 
demikian korban KDRT yang selama ini terdiskriminasi secara hukum dapat mencari keadilan seperti yang diharapkan untuk berbagai bentuk kekerasan yang memang terjadi dan menimpa mereka.

Kekerasan psikis yang menjadi terobosan adalah dalam proses hukumnya antara lain memungkinkan untuk dilakukan visum et psikiatrum sebagai pembuktiannya.

Kekerasan seksual yang salah satunya kekerasan seksual terhadap istri juga menjadi terobosan baru meskipun masih merupakan delik aduan. Tindak pidana khusus ini diatur dalam pasal 8 huruf (a) yang berbunyi "pemaksaan hubungan seksual yang dilakukan terhadap orang yang menetap dalam lingkup rumah tangga tersebut". Hal ini berarti bahwa undang-undang ini sudah tidak lagi memisahkan ranah privat dan publik.

Undang-undang PKDRT merupakan peraturan pertama yang mengatur hak-hak korban. Hak-hak korban KDRT dalam undang-undang Penghapusan kekerasan dalam rumah tangga di pasal 10 antara lain mencakup :

1. Perlindungan dari pihak keluarga, kepolisian, kejaksaan, pengadilan, advokat, lembaga sosial, atau pihak lainnya baik sementara maupun berdasarkan penetapan perintah perlindungan dari pengadilan.

2. Pelayanan kesehatan sesuai dengan kebutuhan medis.

3. Penanganan secara khusus berkaitan dengan kerahasiaan korban

4. Pendampingan oleh pekerja sosial dan bantuan hukum pada setiap proses pemeriksaan sesuai dengan ketentuan peraturan perundang-undangan dan

5. Pelayanan bimbingan rohani.

Sejak advokasi dilakukan , upaya pemulihan korban KDRT menjadi salah satu hal yang tidak terpisahkan dari proses hukum. Dalam hal ini sudah menjadi tanggung jawab bersama antara pemerintah dan penyedia layanan baik layanan medis, psikologis, hukum dan rumah aman.

Upaya pencegahan KDRT merupakan kewajiban bersama antara pemerintah dan masyarakat. Hal ini terkait dengan locus terjadinya KDRT di ranah privat, sehingga pemerintah tidak dapat begitu saja masuk dan memantau rumah tangga tersebut secara langsung. Sehingga dibutuhkan keterlibatan masyarakat dalam memantau dan mencegah terjadinya KDRT di lingkungannya. Kewajiban masyarakat ini diakomodir dalam pasal 14 dan 15 U PKDRT . bahkan dalam pasal 15 dirinci mengenai kewajiban “ Setiap orang yang mendengar, melihat atau mengetahui terjadinya kekerasan dalam rumah tangga wajib melakukan upaya-upaya sesuai dengan batas kemampuannya untuk a) mencegah 
berlangsungnya tidak pidana, b) memberikan perlindungan kepada korban, c) memberikan pertolongan darurat dan d) membantu proses pengajuan permohonan penetapan perlindungan.

\section{Perlindungan Korban Kekerasan Dalam Rumah Tangga di Sidoarjo}

Kekerasan dalam lingkup rumah tangga yang terjadi di wilayah hukum Kabupaten Sidoarjo baik kekerasan fisik dan atau kekerasan psikis. Kekerasan fisik yang terjadi dilakukan berupa pemukulan, tendangan, dan segala yang melukai fisik sang istri. Kekerasan psikis yang dilakukan berupa poligami dan penghinaan terhadap istri. Ranah rumah tangga merupakan ranah privat bagi setiap orang. Tidak semua orang mau dan bisa menceritakan permasalahan yang terjadi dalam rumah tangganya. Hal itu yang menjadi kendala Pemerintah dalam menangani kasus yang terjadi. Karena korban cenderung menutupi kasus kekerasan yang terjadi kepadanya.

Di wilayah hukum Kabupaten Sidoarjo, masih kurang adanya keberanian korban untuk melapor membuat pemerintah kesulitan untuk melakukan pemantauan terhadap warganya. Pemerintah kesulitan untuk memberikan perlindungan karena pemerintah sendiri tidak mengetahui adanya tindak kekerasan.

Melihat fenomena tersebut beberapa aktivis peduli perempuan di Kabupaten Sidoarjo berinisiatif untuk bersatu dan membentuk suatu lembaga yang menggandeng Pemerintah untuk menangani masalah kekerasan perempuan. Lembaga tersebut bernama Pusat Pelayanan Terpadu Perlindungan Perempuan dan Anak (P2TP2A). Pemerintah Kabupaten Sidoarjo bekerja sama dengan P2TP2A untuk menangani kasus kekerasan yang terjadi. Bentuk kerja sama antara Pemerintah Kabupaten dengan P2TP2A adalah ketika ada laporan tindak kekerasan terhadap warga Kabupaten Sidoarjo ke P2TP2A, P2TP2A bertindak sebagai pendamping korban dalam tindak penanganan kasus kekerasan yang terjadi. P2TP2A akan bekerja sama dengan aparat kepolisian sebagai penegak hukum dan RSUD Sidoarjo untuk tindakan medis apabila dibutuhkan oleh korban.

Lembaga yang berjalan berdasarkan SK Bupati Kabupaten Sidoarjo No. 2 Tahun 2007 menjadi lembaga advokasi bagi korban kekerasan terutama korban kekerasan dalam rumah tangga (KDRT) yang meningkat jumlahnya dan semakin marak diberitakan di media. Landasan hukum yang digunakan yaitu Undang-undang No. 23 Tahun 2004 tentang Penghapusan Kekerasan Dalam Rumah Tangga. 
Dalam menangani dan mengurangi jumlah kasus kekerasan yang terjadi P2TP2A mengalami kendala dari segi dana dan jumlah SDM yang dimiliki. Hambatan mengenai keterbatasan SDM diatasi dengan mengadakan pelatihan-pelatihan guna meningkatkan pengetahuan dan kemampuan masing-masing anggota. Selain kendala tersebut, budaya takut dan malu dari korban kekerasan untuk melapor membuat P2TP2A kesulitan menangani masalah tersebut. Kurangnya bentuk sosialisasi P2TP2A tentang perannya membuat masyarakat kurang mengetahui fungsi dari adanya P2TP2A ini.

Kendala-kendala tersebut menyulitkan Pemerintah Kabupaten Sidoarjo bersama P2TP2A untuk mengungkap dan menangani kasus kekerasan yang ada. Pemkab Sidoarjo bersama P2TP2A perlu meningkatkan upaya sosialisasi agar masyarakat Sidoarjo lebih mengetahui dan paham akan adanya dan fungsi P2TP2A.

P2TP2A di Sidoarjo pada awalnya bernama Pusat Perlindungan Perempuan dan Anak (P3A) Sidoarjo yang dibentuk atas prakarsa bersama/sinergi antara Pemerintah Kabupaten Sidoarjo dengan sejumlah LSM dan kalangan masyarakat peduli perempuan yang dilandasi oleh karena banyaknya peristiwa-peristiwa tentang ketidakadilan terhadap perempuan dan anak korban kekerasan yang belum ada lembaga yang secara khusus menangani dengan maksimal.

Selanjutnya seiring dengan perjalanan waktu dan kebutuhan lembaga itu sendiri maka sejak tahun 2012 P3A berganti nama menjadi P2TP2A, kemudian berdasarkan Peraturan Bupati Sidoarjo nomor 59 Tahun 2014 tanggal 22 Desember 2014 menjadi Lembaga Teknis yaitu Pelaksana Teknis Badan (UPTB) P2TP2A Sidoarjo.

Lembaga ini memberikan layanan bersifat terpadu bagi perempuan dan anak korban kekerasan berperspektif gender yang meliputi tindakan medis, multikolegal, psikososial, serta pendampingan hukum.

Bentuk pelayanan P2TP2A Sidoarjo ada 2 (dua) macam:

1. Litigasi (berproses hukum) misalnya: pencabulan/pelecehan seksual, perkosaan dan KDRT.

2. Non Litigasi (tidak diproses hukum) misalnya: antara suami dan istri, orang tua dan anak yang sedang mempunyai masalah.

Terdapat 2 (dua) cara melapor di P2TP2A bila mengalami tindak kekerasan yaitu :

1. Klien atau korban datang langsung ke kantor P2TP2A

2. Klien atau korban tidak mampu datang, maka pengurus P2TP2A akan outreach atau mendatangi tempat kejadian atau mendatangi rumah korban. 
Memperhatikan uraian hasil penelitian sebagaimana tersebut di atas dapat dijelaskan bahwa penanganan KDRT di Kabupaten Sidoarjo ditangani oleh P2TP2A, yang berarti bahwa pasca diundangkannya UU PKDRT, kekerasan dalam rumah tangga tidak dilaporkan kepada kepolisian untuk dilakukan penyidikan adanya kekerasan atau penganiayaan, melainkan dilaporkan kemudian ditangani oleh P2TP2A. Penanganan KDRT oleh P2TP2A sejalan dengan filosofi diundangkannya UU PKDRT sebagaimana tercantum dalam Penjelasan Umum bahwa untuk menjaga keutuhan dan kerukunan rumah tangga yang bahagia, aman, tenteram, dan damai merupakan dambaan setiap orang dalam rumah tangga. Negara Republik Indonesia adalah negara yang berdasarkan Ketuhanan Yang Maha Esa dijamin oleh Pasal 29 Undang-Undang Dasar Negara Republik Indonesia Tahun 1945. Dengan demikian, setiap orang dalam lingkup rumah tangga dalam melaksanakan hak dan kewajibannya harus didasari oleh agama. Hal ini perlu terus ditumbuh kembangkan dalam rangka membangun keutuhan rumah tangga.

Namun dalam penanganan adanya KDRT, banyak kendala tersebut, budaya takut dan malu dari korban kekerasan untuk melapor membuat P2TP2A kesulitan menangani masalah tersebut. Kurangnya bentuk sosialisasi P2TP2A tentang perannya membuat masyarakat kurang mengetahui fungsi dari adanya P2TP2A.

Sebagaimana standar operasional prosedur (SOP) sebagai berikut:
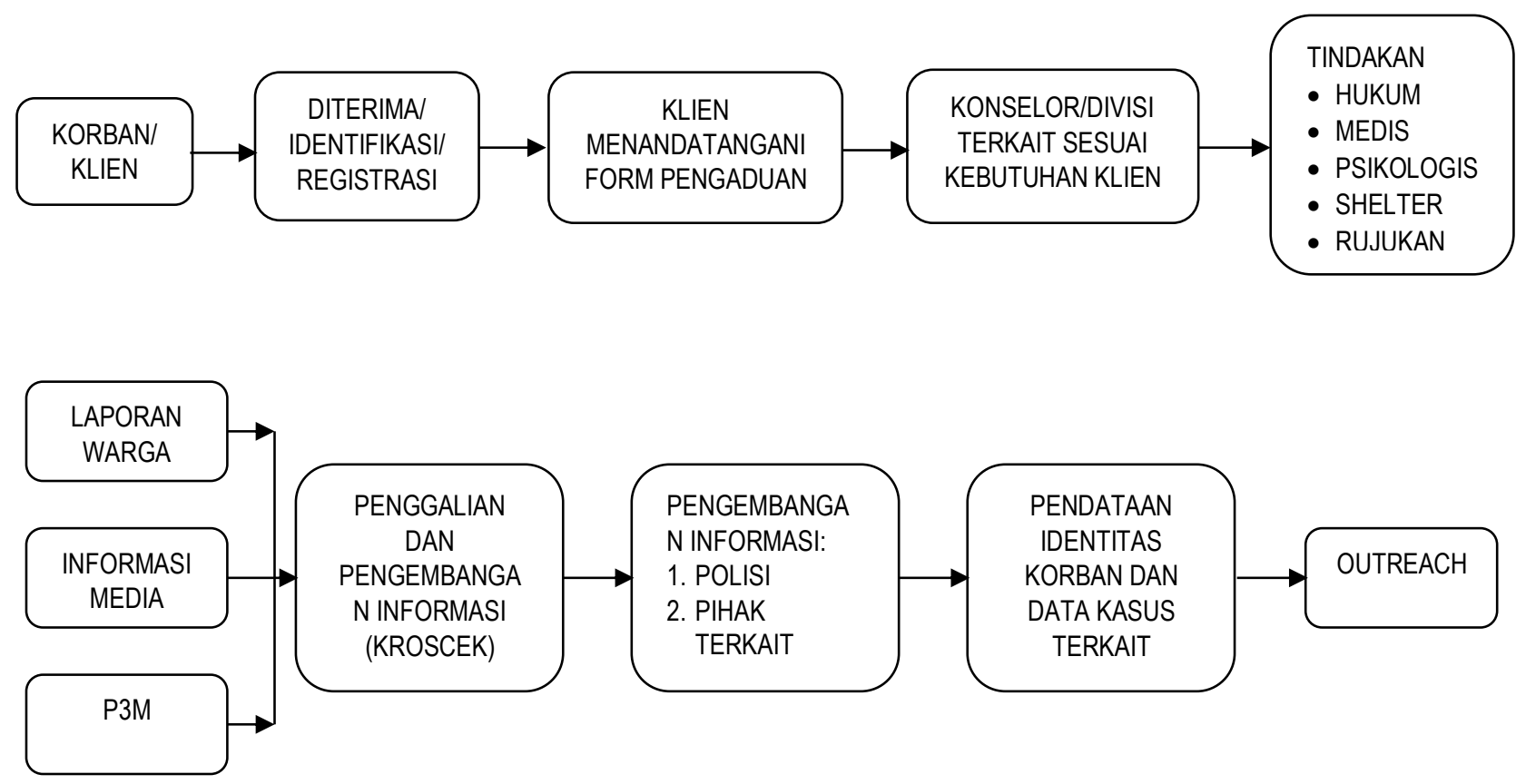


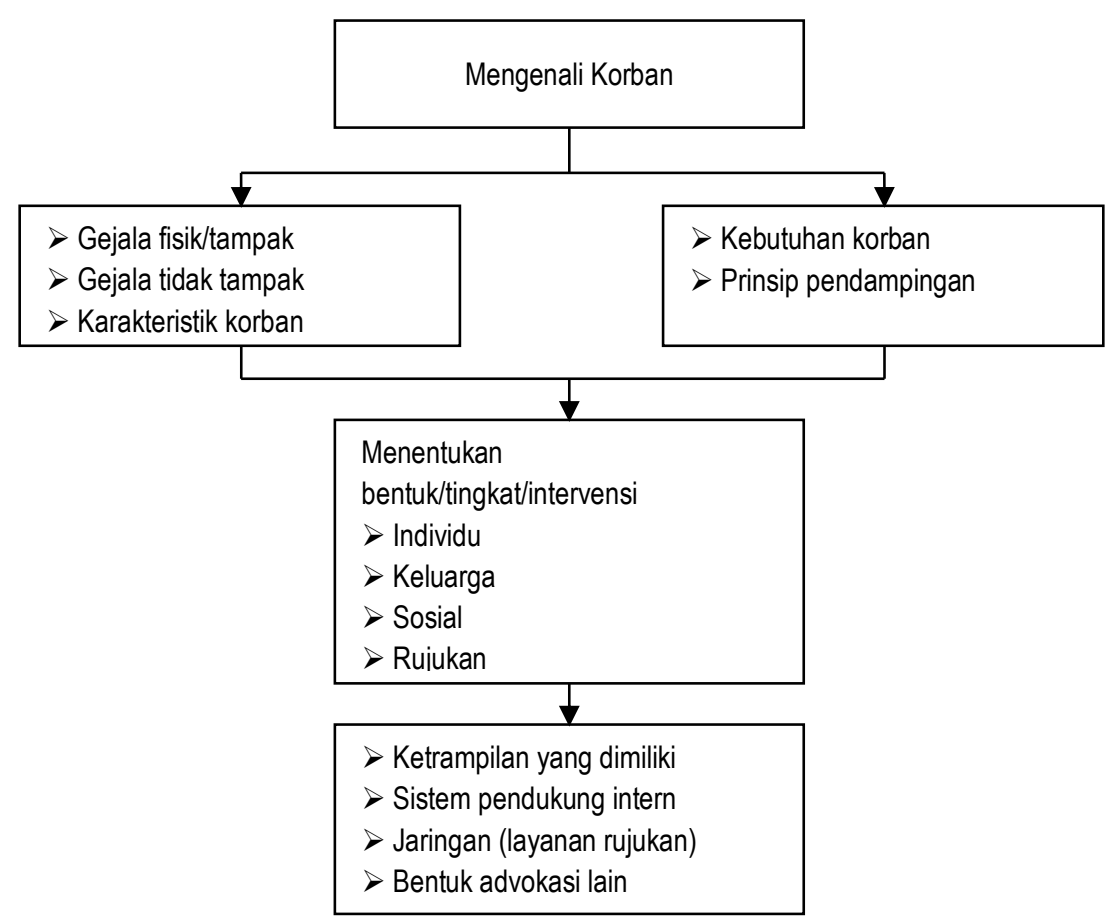

Prinsip-prinsip dasar layanan P2TP2A

1. Klien tidak dikenakan beban biaya apa pun atas dampak layanan yang diperolehnya.

2. Kerahasiaan klien menjadi prioritas penting dalam masa penanganan

3. Tidak melakukan diskriminasi

4. Pelayanan berkeadilan dan menghormati sisi kemanusiaan klien (martabat, harga diri)

5. Pelayanan cepat atau tanpa birokrasi yang mempersulit klien

6. Kepentingan dan kebutuhan klien adalah prioritas utama

Menghindari ketergantungan klien dengan membangkitkan sifat kemandirian baik dalam mengambil keputusan maupun dalam kehidupan klien pasca penanganan shelter.

\section{KESIMPULAN}

Kasus KDRT di Sidoarjo belum banyak dilaporkan oleh para korban, menjadikan salah satu kendala dalam memberikan penanganan dalam upayanya untuk mengurangi atau memperkecil timbulnya korban.

Penanganan korban KDRT dilayani oleh P2TP2A, sehingga telah sejalan dengan UU PKDRT, namun kurang maksimal dalam memberikan penanganan karena korban masih enggan melaporkan adanya KDRT. 


\section{Daftar Pustaka}

Geme, Maria Theresia, Perlindungan Hukum terhadap Masyarakat Adat Dalam Pengelolaan Cagar Alam Watu Ata Kabupaten Ngada, Provinsi Nusa Tenggara Tmur, Disertasi, Malang: Program Doktor Ilmu Hukum Fakultas Hukum Universitas Brawijaya 2012. Himly, Umu, dkk., Penanganan Kasus-Kasus Trafiking Berperspektif Gender oleh Jaksa dan

Hakim, Modul Pelatihan, Malang: Pusat Pengembangan Hukum dan Gender Fakultas Hukum Universitas Brawijaya, The Asia Foundation \& Universitas Negeri Malang (UM Press) 2006

HS, Salim dan Erlies Septiana Nurbani, Penerapan Teori Hukum pada Penelitian Thesis Dan Disertasi, Jakarta: Raja Grafindo Persada 2013.

Konsideran Bagian Menimbang Undang-Undang Republik Indonesia Nomor 23 Tahun 2004 tentang Penghapusan Kekerasan Dalam Rumah Tangga

LBH APIK, Rekomendasi Umum No. 19 tentang Kekerasan Terhadap Perempuan, Jakarta: LBH APIK 2000.

M, Philipus Hadjon dan Tatiek Sri Djatmiati, Argumentasi Hukum, Yogyakarta: Gadjahmada Press 2005.

Prasetyo, Teguh, Hukum Pidana, Cetakan III, Jakarta: Rajawali Press 2012.

Prodjodikoro, Wiryono, Asas-Asas Hukum Pidana di Indonesia, Jakarta: Refika Aditama, 2008.

Raharjo, Satjipto, Ilmu Hukum, Bandung: Citra Aditya Bakti 2000.

Schaffneister, D., N Keijer \& Sutorius, Hukum Pidana, Bandung: Citra Aditya Bhakti 2011.

Sianturi, Tindak Pidana di KUHP Berikut Uraiannya, Jakarta: Alumni KHM, PTHM 1989.

Soeroso, Moerti Hadiati, Kekerasan Dalam Rumah Tangga, Dalam Perspektif Yuridis Victimologi, Jakarta: Sinar Grafika 2010.

Soesilo, KUHP Beserta Penjelasannya Pasal Demi Pasal, Bogor: Poeliteia 1998.

Sugandhi, KUHP dan Penjelasannya, Surabaya: Usaha Nasional 2001.

Undang-Undang Nomor 23 Tahun 2004 Tentang Penghapusan Kekerasan Dalam Rumah Tangga

Wiyanto, Roni, Asas-Asas Hukum Pidana Indonesia, Bandung: Mandar Maju 2012. 